\title{
The Use of Bioacoustic Stimulation of the Respiratory System in Complex Medical Rehabilitation at a Health Resort Facility for Patients who have had COVID-associated Pneumonia
}

\author{
Mikhail Bragin $^{1 *} \mathbb{D}$, Evgeny Goloborodko ${ }^{1} \mathbb{D}$, Gennady Erofeev ${ }^{2}$, Sergey Razinkin ${ }^{1} \mathbb{D}$, Alexey Vladimirovich Sukhinin, \\ Anna Kish ${ }^{1}$ (D), Irina Mikhlik ${ }^{3}$ (D) Ksenia Vladimirovna Zolotareva ${ }^{4}$ \\ ${ }^{1}$ State Research Center, Burnasyan Federal Medical Biophysical Center, Federal Medical Biological Agency, Moscow, Russia; \\ ${ }^{2}$ Central Research Institute, Ministry of Defense, Sergiev Posad, Russia; "Sanatorium and Resort Complex "Privolzhsky", \\ Ministry of Defense, Samara, Russia; ${ }^{4}$ Branch "Volga Clinical Sanatorium", Sanatorium and Resort Complex "Privolzhsky", \\ Ministry of Defense, Samara, Russia
}

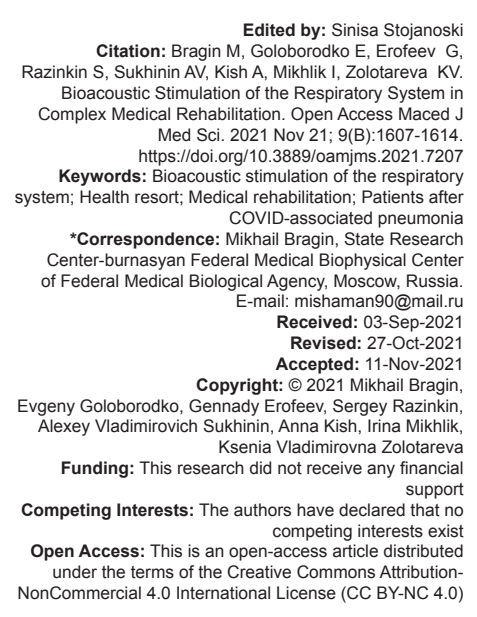

Introduction

Bilateral pneumonia (viral diffuse alveolar injury with microangiopathy) is the most common clinical manifestation of the novel coronavirus infection (COVID-19), a type of viral lung disease characterized by the involvement in the pathological process of interstitial lung tissue, alveolar walls, and vessels, that is, the development of inflammation in all the lung structures involved in gas exchange, which prevents the normal oxygenation of the blood [1], [2], [3], [4], [5], [6].

Events at the stage of medical rehabilitation of patients with coronavirus-related pneumonia

\begin{abstract}
(hACKOUND: In the context of the COVID-19 pandemic, the relevance of rehabilitation measures for patients

AIM: The study aimed to review the effect of bioacoustic stimulation of the respiratory system (BSRS) with high-intensity low-frequency sounds on the dynamics of functional indicators of the respiratory system and the cardiovascular system, as well as indicators of psychoemotional and somatic states, the severity of post-traumatic stress disorders (PTSD) and cognitive capabilities in patients who have had COVID-associated pneumonia in the

MATERIALS AND METHODS: The randomized controlled open parallel prospective clinical study involved 28 patients bilateral polysegmental pneumonia (COVID-associated pneumonia) of moderate to severe severity. Spirometry, pulse oximetry, compression oscillometry, bioelectrography, Mississippi Scale (civil version), and cognitive speed test

RESULTS: According to significant differences in changes in the indexes of external respiration, cardiac activity, psychological status, and the intensity of PTSD in patients of the main and control groups before and after a course of rehabilitation measures, it has been reliably established that the use of BSRS as a part of a complex of rehabilitation measures significantly increases the effectiveness of medical rehabilitation at a health resort for patients after CONCLUSION: The possibility and feasibility of using medical technology of BSRS with high-intensity low-frequency sound in complex medical rehabilitation of patients after COVID-associated pneumonia at the health resort stage have been scientifically substantiated.
\end{abstract}

(COVID-associated pneumonia), aimed at restoration of function of external respiration, transport and utilization of oxygen by tissues, organs, and systems, the restoration of tolerance to stress, psycho-emotional stability, daily activities, and participation in daily lifearecrucial to restoring and optimizing the results of intensive and specialized medical care with COVID-19 [1], [3], [4], [5], [6], [7].

As practice has shown, the implementation of the second stage of medical rehabilitation at health resorts immediately after the treatment of patients with COVID-associated pneumonia in the hospital setting is significant for achieving this goal [6], [7], [8], [9].

At present, various programs of the second stage of medical rehabilitation of patients with the 
post-COVID syndrome at health resorts have been developed and implemented in practical healthcare [3], [5], [7], [8], [9], including methods and means that have proven to be effective [6]. During the implementation of these programs, it was shown that complex rehabilitation measures with the use of various natural and preconditioned therapeutic physical factors contributed to an increase in the overall adaptive potential, improvement of the functional state of the cardiorespiratory system, correction of vegetative imbalance, and increased tolerance to physical activity [9].

At the same time, despite the high effectiveness of these rehabilitation measures noted by several researchers [3], [5], [7], [8], [9], conducting high-quality randomized controlled clinical trials to evaluate new various physical methods of rehabilitation of patients after COVID-associated pneumonia, which can serve as a basis for the development of future valid clinical recommendations, is an important task in the field of restorative medicine, physiotherapy and health resort therapy [6], especially in terms of the ongoing pandemic COVID-19 [6], [8], [9], [10], [11], [12].

It should be noted that the specific tasks of respiratory rehabilitation in COVID-19, including in patients after COVID-associated pneumonia, include the elimination of inflammatory foci, improvement of bronchial conduction and uniformity of lung ventilation, elimination of dissociation between alveolar ventilation and pulmonary blood flow, improvement of bronchial drainage function, prevention of early expiratory closure of the airways, and economization of the respiratory muscles function through increasing their power and synkinesis, that is, the implementation of adequate gas exchange with minimal stress of compensatory mechanisms [7], [10].

At present, to solve these problems, including at the health resort stage of rehabilitation, a wide range of methods and means are used that implement various types of physical training, a system of breathing exercises, yoga elements, sound and drainage gymnastics, postural drainage, normobaric barotherapy, magnetic therapy, and other therapeutic physical factors [1], [4], [5], [6], [7], [13], [14], [15], [16], [17], [18].

The method that, based on the results of its use in sports medicine, can allow solving some of the aforementioned tasks of medical rehabilitation of patients after COVID-associated pneumonia is bioacoustic stimulation of the respiratory system (BSRS) with high-intensity low-frequency sounds [19], [20], [21], [22], [23].

The BSRS method is based on the biological effects of the interaction of a high-intensity sound wave with the human respiratory tract at individually selected resonant frequencies [19], [20], [23]. In this case, the effects of high-intensity sounds at a low tone frequency result in the opening of extra alveoli, reducing the tone of smooth muscles of the respiratory bronchioles and, consequently, increasing their cross-sectional area, that is, ultimately, increasing lung capacity, improving gas exchange and, therefore, increasing the functional reserves of the respiratory system of the human body [15], [20], [23], [24].

Thus, the use of BSRS in 114 professional cyclists showed that $98.3 \%$ of athletes had a marked increase in the functional reserves of the body by increasing lung capacity by $5-15 \% ; 87.9 \%$ had an increase in chest excursion and an increase in the time of breath-holding during the exhale; $94.8 \%$ had an increase in peak power during the Wingate test, and $84.5 \%$ had a minimally $60 \%$ decline in maximum oxygen debt after performing aerobic and anaerobic physical activity. At the same time, there was no negative effect on the clinical, hematological, and biochemical parameters of the body [19], [20].

Based on this and the above-mentioned features of respiratory disorders in patients with COVID-associated pneumonia and the rehabilitation tasks carried out in this case, it was suggested that the use of BSRS as one of the methods of medical rehabilitation of patients after COVID-associated pneumonia would allow those patients to increase the vital capacity of the lungs and, as a result, improve gas exchange in the lungs and increase the body's tolerance to physical exertion, as well as improve the psycho-emotional state and reduce the severity of post-traumatic stress disorder (PTSD). It was assumed that the use of BSRS, characterized in contrast to the physical methods currently used in accordance with [1] for the rehabilitation of patients after COVID-associated pneumonia [3], [4], [5], [6], [7], [8], [9], [13], [14], [15], by direct exposure of high-intensity low-frequency sounds on the respiratory system of the patient and the corresponding biological effects of their interaction with this system, will significantly improve the effectiveness of medical rehabilitation at the resort stage of patients who suffered COVID-associated pneumonia. Previously, research on the assessment of the possible effectiveness of BSRS as a physical method of medical rehabilitation of patients who suffered COVID-associated pneumonia has not been conducted.

In this regard, the study aimed to investigate the influence of BSRS - a new medical technology for increasing the functional potential of the human body - on the dynamics of the functional parameters of the respiratory system and the cardiovascular system, as well as indicators of emotional and somatic states, the severity of PTSD, and cognitive abilities in patients undergoing COVID-19, and to study the possibility and feasibility of using this technique in complex medical rehabilitation at the health resort stage for patients with COVID-associated pneumonia. 


\section{Materials and Methods}

The study involved 28 patients enrolled immediately after discharge from the hospital for medical rehabilitation at a health resort after having from COVID-19 of moderate to heavy severity complicated by community-acquired bilateral polysegmental pneumonia (COVID-associated pneumonia) of moderate to heavy severity. The criteria for participation in the study included informed consent of the patient; the age of patients was between 40 and 65 years; patients were objectively diagnosed with moderate-to-severe COVIDassociated pneumonia in the hospital; and patients received the same rehabilitation measures prescribed by their attending physician in accordance with [1].

The patients were divided into two groups. The main group included 20 patients (16 women and 4 men, average age: $54.1 \pm 2.4$ years) and the control group included eight patients (four men and four women, average age: $55.5 \pm 4.1$ years).

The patients of the main group, in addition to the recommended rehabilitation measures carried out for 14 days (physiotherapy procedures, physical therapy, etc.) [1], were given 5 sessions of BSRS every other day, starting from the $2^{\text {nd }}$ or $3^{\text {rd }}$ day of their stay at a health resort. Each session included 5 stimulation procedures lasting $1.5 \mathrm{~min}$ with an interval of $30 \mathrm{~s}$ between them. The stimulation was carried out at the duration of the inhalation/exhalation phase $T_{f}=3 \mathrm{~s}$ in the frequency range of $23-38 \mathrm{~Hz}$ with the amplitude of the polyharmonic sound signal, which was $70 \%$ of the maximum level of the stimulating sound pressure equal to $130 \mathrm{~dB}(63.2 \mathrm{~Pa})$. In the control group, rehabilitation measures were carried out under the established procedure (without BSRS).

BSRS was carried out using a specialized acoustic system [12], presented in the form of a hardware and software complex (HSC) shown in Figure 1.

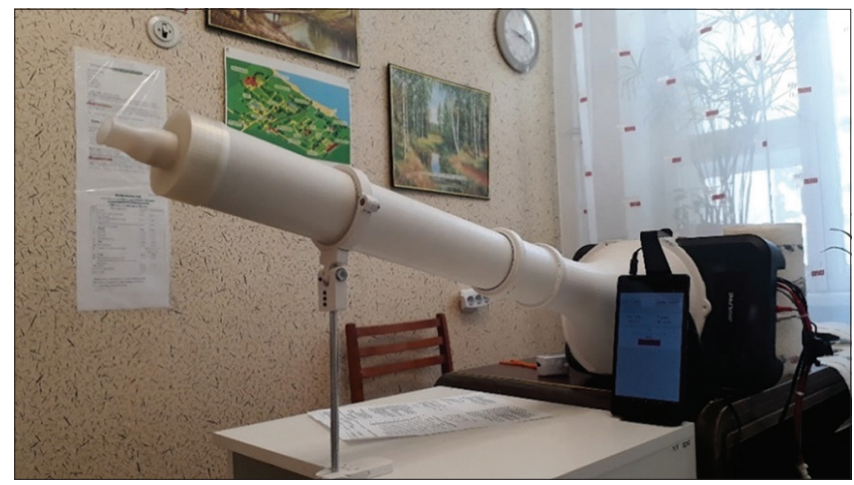

Figure 1: Hardware and software complex for human bioacoustic stimulation of the respiratory system

During BSRS, in patients of the main group, oxygen saturation $\left(\mathrm{SaO}_{2}\right)$ was determined directly before and after each session with a medical pulse oximeter Armed YX300 and forced indicators of external respiration the forced expiratory volume in $1 \mathrm{~s}$ (FEV1) and forced vital capacity (FVC) were registered using the USPS-01 spirometry test and also measured on a scale from 0 to 10 , where 5 points were neutral. A subjective evaluation of the effectiveness of the procedure was also performed by the patients.

Before and after the BSRS course (five sessions with five procedures in each; at the end of the whole course) a spirometric test was performed in the patients of the main group using a MicroLoop electronic medical spirometer, a bio-electrographic study using the Diamed-MBS HSC [22] to assess psycho-emotional and somatic states; a compression oscillometry study on the CAB TsGosm-Globus device to assess cardiovascular system indicators; assessment of rates of simple numbers addition speed (automated speed cognitive test) to assess cognitive abilities. In addition, based on the fact that many people recovering from COVID-19, according to Soloveva et al. [25], will face PTSD and some of them will go into a protracted mental disorder in the form of so-called coronavirus syndrome, the main group of patients before and after rehabilitation was assessed for PTSD severity on the Mississippi scale (civilian version).

Similar studies were also conducted in patients of the control group before and after rehabilitation measures (before the discharge from the health resort). Statistical data processing was performed using Statistica 10.0 software (StatSoft Inc., USA). The values of the assessed indicators of patients' condition before and after the course of rehabilitation measures were compared using the nonparametric Wilcoxon signed-rank test for dependent samples. Differences were considered statistically significant at $p<0.05$.

\section{Results}

The results of the assessment of $\mathrm{SaO}_{2}$, the forced external respiration indicators, and the subjective assessment of the effectiveness of the procedure by patients of the main group during BSRS are presented in Table 1.

As a result of the conducted study, it was found that $70-80 \%$ of patients, already starting from the first or second session of BSRS, had subjectively noted that they breathed more easily ("it became easier to breathe," "I breathe more freely") and that the inhalation and exhalation had become deeper ("I inhale and exhale more," "I got more intensive breath"). Starting from the third session of stimulation, on average in the group of patients, there was a significant $(p<0.05)$ increase in the values of subjective assessment of the effectiveness of the procedure by patients compared to the first session. 
Table 1: The results of the evaluation of $\mathrm{SaO}_{2}$, forced external respiration indicators, and subjective assessment of the effectiveness of the procedure by patients of the main group during the BSRS course $(n=20)$

\begin{tabular}{|c|c|c|c|c|c|c|c|c|c|c|}
\hline \multirow[t]{3}{*}{ Indicator } & \multicolumn{10}{|c|}{ Bioacoustic stimulation session number } \\
\hline & \multicolumn{2}{|l|}{$1^{\text {st }}$ session } & \multicolumn{2}{|l|}{$2^{\text {nd }}$ session } & \multicolumn{2}{|l|}{$3^{\text {rd }}$ session } & \multicolumn{2}{|l|}{$4^{\text {th }}$ session } & \multicolumn{2}{|l|}{$5^{\text {th }}$ session } \\
\hline & Before & After & Before & After & Before & After & Before & After & Before & After \\
\hline $\mathrm{SaO} 2, \%$ & $97.5 \pm 0.3$ & $98.6 \pm 0.3^{*}$ & $97.0 \pm 0.4$ & $98.7 \pm 0.3^{*}$ & $97.1 \pm 0.3$ & $98.3 \pm 0.3^{*}$ & $97.4 \pm 0.3$ & $98.6 \pm 0.2^{*}$ & $97.3 \pm 0.3$ & $98.7 \pm 0.3^{*}$ \\
\hline FEV1, I & $2.17 \pm 0.14$ & $2.13 \pm 0.13^{*}$ & $2.07 \pm 0.11$ & $2.20 \pm 0.12^{*}$ & $2.12 \pm 0.11$ & $2.16 \pm 0.11$ & $2.08 \pm 0.11$ & $2.11 \pm 0.10$ & $2.17 \pm 0.10$ & $2.23 \pm 0.12^{*}$ \\
\hline FEV1, \% of the proper value & $71.52 \pm 3.07$ & $70.10 \pm 3.09^{*}$ & $68.75 \pm 3.25$ & $72.38 \pm 2.70^{*}$ & $70.05 \pm 3.05$ & $71.58 \pm 2.75$ & $68.92 \pm 2.87$ & $69.99 \pm 2.60$ & $71.15 \pm 2.78$ & $72.94 \pm 3.12$ \\
\hline FEV1, change in $\%$ & $-1.41 \pm 0.47$ & & $3.63 \pm 1.24$ & & $1.53 \pm 1.43$ & & $1.07 \pm 1.07$ & & $1.79 \pm 0.85$ & \\
\hline FVC, I & $2.36 \pm 0.14$ & $2.36 \pm 0.15$ & $2.24 \pm 0.11$ & $2.42 \pm 0.12^{*}$ & $2.31 \pm 0.12$ & $2.40 \pm 0.11$ & $2.26 \pm 0.12$ & $2.32 \pm 0.10$ & $2.38 \pm 0.11$ & $2.44 \pm 0.13$ \\
\hline FVC, $\%$ of the proper value & $61.80 \pm 2.62$ & $61.88 \pm 2.93$ & $52.55 \pm 2.14$ & $56.42 \pm 1.80^{*}$ & $53.96 \pm 2.04$ & $56.48 \pm 1.91$ & $52.83 \pm 1.98$ & $54.37 \pm 1.69^{*}$ & $55.31 \pm 1.80$ & $56.83 \pm 2.25$ \\
\hline FVC, change in \% & $0.08 \pm 0.88$ & & $3.87 \pm 1.17$ & & $2.52 \pm 1.13$ & & $1.54 \pm 0.75$ & & $1.37 \pm 0.91$ & \\
\hline $\begin{array}{l}\text { Subjective assessment of } \\
\text { the procedure, score }\end{array}$ & $5.7 \pm 0.2$ & & $6.1 \pm 0.3$ & & $6.1 \pm 0.3^{*}$ & & $6.3 \pm 0.3^{*}$ & & $6.9 \pm 0.3^{*}$ & \\
\hline
\end{tabular}

At the same time, after each stimulation session, on average, a significant $(p<0.05)$ increase in SaO2, a $1-6 \%$ increase in forced respiratory parameters FEV1 and FVC, and a $1-7 \%$ increase of the proper values, respectively, was registered in patients in the group. A significant $(p<0.05)$ increase in FEV1 and FVC on average in the group was determined after the second, fourth, and fifth BSRS sessions. It should be noted that an increase in FEV1 and FVC by $3.4-12.2 \%$ and $2.3-13.9 \%$ of the proper values, respectively, after the second session of BSRS was observed in $65 \%$ of patients.

The generalized results of spirometric, bioelectrographic, and oscillometric tests, as well as the results of evaluating the simple numbers addition speed and the severity of PTSD before and after a course of medical rehabilitation measures in patients of the main and control groups, are presented in Tables 2 and 3 .

The spirometric test showed that in patients after the course of BSRS, on average in the group, the external respiration indicators VC, FEV1, PEF, and MEF75 had increased significantly ( $p<0.05$ ). Positive changes in those indicators were observed in 70-80\% of patients. Thus, an increase in VEL by $1-45 \%$ from the proper values was noted in $80 \%$, an increase in FEV1 by $4-43 \%$ was noted in $70 \%$, an increase in PEF by $1-44 \%$ was noted in $80 \%$, and an increase in MEF 75 by $5-48 \%$ was noted in $80 \%$ of patients. The FVC index had not significantly increased on average in the group, although positive changes by $1-39 \%$ in this indicator were observed in $80 \%$ of patients.

On average, assessment of the psychoemotional and somatic state using the DiamedMBS HSC showed, compared with the baseline level (immediately before the first BSRS session), a significant decrease in the number of complaints and improved psychological status ( $p<0.05$ ), as well as physical and emotional condition. These changes were observed in $45-75 \%$ of patients.

The compression oscillometry showed a significant decrease in the SO of the heart on average in the group $(p<0.05)$ after a course of BSRS. However, these changes were observed in $65 \%$ of patients. When assessing PTSD according to the Mississippi scale (civilian version), on average in the group patients showed a significant decrease in the severity of PTSD from $80.8 \pm 3.6$ to $76.6 \pm 3.8$ points $(p<0.05)$ after the course of BSRS and overall medical rehabilitation. It should be noted that these values roughly correspond to the indicators of firefighters (73.79 \pm 13.05 points) and refugees without PTSD (79.70 \pm 18.19 points) [26].

The number of complaints significantly decreased in patients of the control group when assessing the psychosomatic state at the DiamedMBS HSC ( $p<0.05)$. A decrease in the number of complaints was observed in $100 \%$ of patients. When conducting spiro- and oscillometric tests, there were no significant changes in the aforementioned indicators of external respiration and SO of the heart after a course of rehabilitation measures on average for the group. At the same time, positive changes in external respiration indicators were observed in $37.5-62.5 \%$ of patients. Thus, an increase in VC by $3-23 \%$ from the proper values was noted in $62.5 \%$, an increase of FEV1 by $3-9 \%$ in $50 \%$, an increase of FVC by $6-7 \%$ in $37.5 \%$ of patients, an increase of PEF by $1-42 \%$ in $62.5 \%$, and an increase of MEF 75 by $4-44 \%$ in $50 \%$ of patients.

It should be particularly noted that in the main and control groups, the indicators of the simple numbers addition speed (cognitive speed test) generally improved. Thus, in both groups, after the rehabilitation measures, including BSRS, compared with the initial level, the number of decisions per minute significantly increased ( $p<0.05)$, respectively, the average speed of their adoption significantly decreased $(p<0.05)$, and the calculated "Reliability coefficient" indicator reliably increased $(p<0.05)$.

\section{Discussion}

The results of the conducted clinical study provide convincing evidence that during medical rehabilitation of patients who had COVID-associated pneumonia, the new medical technology to improve the functional capabilities of the human body based on BSRS was successfully applied [16], [17], [18], [19], [20], [21]. We also obtained data characterizing subsequent positive changes in the functional indices of the respiratory and cardiovascular systems, 
Table 2: The results of spirometric, bio-electrographic, and oscillometric tests before and after a course of medical rehabilitation measures in patients of the main and control groups

\begin{tabular}{|c|c|c|c|c|}
\hline \multirow[t]{2}{*}{ Indicator } & \multicolumn{2}{|c|}{ Main group $(n=20)$} & \multicolumn{2}{|c|}{ Control group $(n=8)$} \\
\hline & Before & After & Before & After \\
\hline \multicolumn{5}{|c|}{ Spirometric test (with a MicroLoop medical spirometer) } \\
\hline VC, I & $3.11 \pm 0.22$ & $3.35 \pm 0.17^{*}$ & $3.18 \pm 0.40$ & $3.42 \pm 0.44$ \\
\hline VC, $\%$ of the proper value & $91.5 \pm 4.3$ & $98.9 \pm 3.5^{*}$ & $90.5 \pm 6.7$ & $95.5 \pm 3.8$ \\
\hline FEV1, I & $2.27 \pm 0.17$ & $2.48 \pm 0.16^{*}$ & $2.40 \pm 0.33$ & $2.39 \pm 0.34$ \\
\hline FEV1, $\%$ of the proper value & $79.8 \pm 3.4$ & $87.9 \pm 3.9^{*}$ & $82.4 \pm 6.4$ & $81.1 \pm 4.8$ \\
\hline FVC, I & $2.59 \pm 0.18$ & $2.77 \pm 0.19$ & $2.58 \pm 0.36$ & $2.61 \pm 0.37$ \\
\hline FVC, $\%$ of the proper value & $76.6 \pm 3.2$ & $81.8 \pm 3.3$ & $73.6 \pm 6.9$ & $73.5 \pm 5.6$ \\
\hline $\mathrm{PEF}, \mathrm{ml} / \mathrm{min}$ & $329.9 \pm 27.8$ & $389.9 \pm 26.1^{*}$ & $372.5 \pm 42.1$ & $389.4 \pm 61.3$ \\
\hline PEF, $\%$ of the proper value & $77.6 \pm 4.6$ & $92.1 \pm 3.9^{*}$ & $85.4 \pm 4.8$ & $87.3 \pm 6.8$ \\
\hline FEV1/FVC,\% & $88.3 \pm 2.6$ & $89.9 \pm 1.6$ & $93.8 \pm 2.7$ & $92.3 \pm 2.8$ \\
\hline FEV1/FVC, $\%$ of the proper value & $112.5 \pm 3.2$ & $114.8 \pm 2.0$ & $119.6 \pm 3.4$ & $117.9 \pm 3.4$ \\
\hline MEF 75, l/s & $4.83 \pm 0.36$ & $5.59 \pm 0.35^{*}$ & $5.94 \pm 0.71$ & $6.14 \pm 1.08$ \\
\hline MEF $75, \%$ of the proper value & $78.5 \pm 4.7$ & $90.8 \pm 4.5^{\star}$ & $92.9 \pm 6.5$ & $93.9 \pm 10.2$ \\
\hline MEF $50,1 / \mathrm{s}$ & $3.42 \pm 0.28$ & $3.77 \pm 0.30$ & $4.31 \pm 0.53$ & $4.13 \pm 0.55$ \\
\hline MEF $50, \%$ of the proper value & $83.8 \pm 6.4$ & $92.0 \pm 6.5$ & $101.5 \pm 4.5$ & $97.9 \pm 8.2$ \\
\hline MEF 25, l/s & $1.70 \pm 0.23$ & $1.66 \pm 0.15$ & $1.94 \pm 0.32$ & $2.03 \pm 0.27$ \\
\hline MEF $25, \%$ of the proper value & $106.6 \pm 13.9$ & $108.0 \pm 10.4$ & $121.8 \pm 16.1$ & $131.9 \pm 19.5$ \\
\hline \multicolumn{5}{|l|}{ Bioelectrographic test (Diamed-MSB HSC) } \\
\hline Physical condition, score & $3.3 \pm 0.19$ & $3.7 \pm 0.21$ & $3.1 \pm 0.23$ & $3.5 \pm 0.19$ \\
\hline Emotional state, score & $3.4 \pm 0.21$ & $3.8 \pm 0.20$ & $3.4 \pm 0.26$ & $3.4 \pm 0.18$ \\
\hline Complaints, number & $19.4 \pm 2.27$ & $12.9 \pm 1.95^{\star}$ & $22.1 \pm 3.46$ & $14.3 \pm 3.64^{*}$ \\
\hline $\mathrm{HR}$, beats per min & $80.7 \pm 2.57$ & $83.9 \pm 2.59$ & $78.1 \pm 2.92$ & $77.0 \pm 3.81$ \\
\hline Stress index, standard units & $859.11 \pm 152.18$ & $1,203.58 \pm 270.79$ & $1,979.3 \pm 961.8$ & $1,080.8 \pm 315.4$ \\
\hline PARS, score & $5.0 \pm 0.39$ & $5.7 \pm 0.41$ & $6.3 \pm 0.6$ & $4.9 \pm 0.48$ \\
\hline Area without filter, standard units & $22,290.1 \pm 760.9$ & $23,286.95 \pm 600.76$ & $23,987.5 \pm 649.7$ & $23,174.6 \pm 828.3$ \\
\hline Symmetry without filter, standard units & $92.4 \pm 1.4$ & $94.3 \pm 0.7$ & $95.6 \pm 0.6$ & $94.1 \pm 1.2$ \\
\hline Area with filter, standard units & $28,249.6 \pm 574.3$ & $28,714.1 \pm 700.2$ & $29,055.3 \pm 711.4$ & $29,245.9 \pm 498.4$ \\
\hline Symmetry with filter, standard units & $97.1 \pm 0.4$ & $96.9 \pm 0.6$ & $97.8 \pm 0.3$ & $97.1 \pm 0.7$ \\
\hline Psychological status, standard units & $-16.8 \pm 9.3$ & $3.7 \pm 11.7^{\star}$ & $0.1 \pm 19.2$ & $13.1 \pm 16.9$ \\
\hline Main risks, units & $0.9 \pm 0.1$ & $1.0 \pm 0.0$ & $1.0 \pm 0.0$ & $1.0 \pm 0.0$ \\
\hline Related risks, units & $2.7 \pm 0.4$ & $2.7 \pm 0.3$ & $2.9 \pm 0.5$ & $2.8 \pm 0.5$ \\
\hline The number of outputs, units & $5.8 \pm 2.5$ & $9.0 \pm 2.8$ & $10.4 \pm 5.0$ & $4.8 \pm 1.6$ \\
\hline \multicolumn{5}{|c|}{ Cardiovascular system test (compression oscillometry) } \\
\hline $\mathrm{SBP}, \mathrm{mmHg}$ & $122.1 \pm 3.0$ & $121.1 \pm 3.2$ & $125.9 \pm 5.6$ & $122.0 \pm 6.0$ \\
\hline $\mathrm{DBP}, \mathrm{mmHg}$ & $81.3 \pm 3.2$ & $80.5 \pm 3.0$ & $86.3 \pm 3.9$ & $81.8 \pm 4.6$ \\
\hline PBP, $\mathrm{mmHg}$ & $110.3 \pm 2.9$ & $109.6 \pm 3.1$ & $115.3 \pm 4.4$ & $111.4 \pm 5.8$ \\
\hline Pulse, beats per min & $80.0 \pm 2.7$ & $84.6 \pm 2.7$ & $78.3 \pm 2.9$ & $78.9 \pm 3.7$ \\
\hline $\mathrm{CO}, \mathrm{l} / \mathrm{min}$ & $5.54 \pm 0.13$ & $5.53 \pm 0.13$ & $5.63 \pm 0.31$ & $5.64 \pm 0.30$ \\
\hline $\mathrm{so}, \mathrm{ml}$ & $70.9 \pm 2.8$ & $66.8 \pm 2.5^{*}$ & $72.9 \pm 5.6$ & $72.5 \pm 4.7$ \\
\hline PVR, dynes* ${ }^{*} \mathrm{~cm}-5 / \mathrm{s}$ & $1,341.8 \pm 37.0$ & $1,317.0 \pm 31.7$ & $1,409.1 \pm 81.7$ & $1,307.0 \pm 60.5$ \\
\hline Functional state (FS), standard units & $0.484 \pm 0.05$ & $0.434 \pm 0.04$ & $0.510 \pm 0.04$ & $0.509 \pm 0.06$ \\
\hline
\end{tabular}

psycho-emotional and somatic states, PTSD, and cognitive abilities in these patients as a result of its use.

Thus, during and after the complex of rehabilitation measures, including the BSRS course (five sessions with five procedures every other day), patients who had COVID-associated pneumonia showed subjective improvement of breathing and deepening of inhalation and exhalation, as well as improvement of general well-being. Objective data also showed a significant $(p<0.05)$ increase in $\mathrm{SaO}_{2}$ and external respiration (vital capacity of lungs, volume of the first second forced exhalation, peak exhalation rate, and instantaneous volume rate after exhalation of $75 \%$

Table 3: The results of the evaluation of the simple numbers addition speed and the severity of PTSD before and after a course of medical rehabilitation in patients of the main and control groups

\begin{tabular}{|c|c|c|c|c|}
\hline \multirow[t]{2}{*}{ Indicator } & \multicolumn{2}{|c|}{ Main group $(n=20)$} & \multicolumn{2}{|c|}{ Control group $(n=8)$} \\
\hline & Before & After & Before & After \\
\hline \multicolumn{5}{|c|}{ Evaluation of the simple numbers addition speed (cognitive speed test) } \\
\hline $\begin{array}{l}\text { Number of solutions, } \\
\text { units }\end{array}$ & $38.3 \pm 3.3$ & $41.5 \pm 2.9^{*}$ & $36.6 \pm 1.7$ & $43.0 \pm 2.2^{*}$ \\
\hline $\begin{array}{l}\text { Erroneous actions, } \\
\text { units }\end{array}$ & $2.4 \pm 0.5$ & $2.9 \pm 0.9$ & $3.6 \pm 1.1$ & $3.0 \pm 1.1$ \\
\hline Average speed, $\mathrm{ms}$ & $1791.4 \pm 147.8$ & $1581.6 \pm 112.7^{*}$ & $1660.1 \pm 76.2$ & $1422.5 \pm 71.4^{*}$ \\
\hline SiPPY, standard units & $0.512 \pm 0.04$ & $0.530 \pm 0.04$ & $0.469 \pm 0.03$ & $0.524 \pm 0.04$ \\
\hline $\begin{array}{l}\text { Reliability coefficient, } \\
\text { standard units }\end{array}$ & $0.472 \pm 0.03$ & $0.499 \pm 0.03^{*}$ & $0.442 \pm 0.03$ & $0.504 \pm 0.03^{\star}$ \\
\hline \multicolumn{5}{|c|}{ PTSD severity assessment (Mississippi scale, civil version) } \\
\hline PTSD severity, score & $80.8 \pm 3.6$ & $76.6 \pm 3.8^{*}$ & $75.0 \pm 3.6$ & $76.1 \pm 4.7$ \\
\hline
\end{tabular}

of the FVC of lungs), improvement of cardiac activity, psychological status, and physical and emotional states, as well as reliable $(p<0.05)$ decrease of PTSD severity and increase of cognitive abilities. This corresponds to the purpose of pulmonary rehabilitation of patients after COVID-associated pneumonia - the restoration of functions of external respiration, transport and utilization of oxygen by tissues, organs, and systems, tolerance to physical activity, and psycho-emotional stability [1], [3], [6], [7].

The presented data support the assumption made at the time of the study, based on the effectiveness of BSRS in sports medicine [17], [18], [19] and the features of respiratory dysfunction in COVID-associated pneumonia [1], [2], [3], [4], [5], [6], that the use of BSRS as a method of medical rehabilitation in patients after COVID-associated pneumonia will increase lung capacity and, as a result, improve lung gas exchange and increase exercise tolerance in these patients, as well as to improve the psycho-emotional condition and reduce the severity of $\mathrm{PTSD}$.

The data obtained correlate with the results of studies in which the positive effect of low-frequency sound vibration (LFSV), particularly infrasound, on the respiratory system of humans and experimental animals was shown when exposed to these oscillations in certain conditions [27], [28], [29] and it was suggested 
that LFSV can be used as a physical medical treatment factor [27].

For example, in the study [27], it has been experimentally shown that LFSV causes significant changes in external respiration, which occur already at the next respiratory cycle after exposure and are characterized by a decrease in respiration (bradypnea), an increase in the duration of the inhalation phase, a change in the shape of the respiratory pattern with an equal probability at all frequencies of acoustic stimulation. Based on these results, as well as the data obtained in this study on the sensory perception of lowintensity LFSV by auditory receptors, skin mechanic receptors, muscle spindles, and visceroreceptors of the heart, we justifiably claim that these results, together with the developed complex of methods for adequate modeling and evaluation of the effects of LFSV, can be used to create new methods of therapeutic acoustic effects on the body to correct its functional state.

A study of hygienic aspects of human exposure to LFSV [28], [29] involving volunteer testers recorded an increase (1.2-1.5 times) in exhaled air volume immediately after exposure to LFSV with a sound pressure level up to $140 \mathrm{~dB}$ for 1-4 min. The range of frequencies causing this effect varied according to the individual parameters of height and constitution of the tester. Spirometric measurements at 5 and 15 min after LFSV exposure showed a tendency for the values to return to baseline. A detailed study of this fact revealed that the increase in lung vital capacity was based on the opening of the reserve alveoli of the lung tissue by exposing them to high-intensity sound waves at resonant frequencies of the bronchopulmonary tract.

Based on the aforesaid, it also seems possible to conclude that the use of BSRS can successfully solve a significant part of tasks of respiratory rehabilitation (the improvement of bronchial conduction and uniformity of ventilation, elimination of dissociation between alveolar ventilation, and pulmonary blood flow, etc.) in patients after COVID-associated pneumonia, providing realization of adequate gas exchange with minimal tension of compensatory mechanisms [7], [10]. Similar problems are solved in the treatment of medical (pulmonological and pulmonary) rehabilitation of patients with other acute and chronic lung diseases, as respiratory function defects in respiratory diseases, including chronic obstructive pulmonary disease (COPD), are most often associated with a change in the mechanism of the respiratory act (defects of the correct ratio of the inhalation phase, exhalation phase and pause, the appearance of shallow and rapid breathing, and discoordination of respiratory movements), which leads to pulmonary ventilation defects, gas exchange defects in the lungs and, as a result, to a decrease in the body's tolerance to physical exertion [10], [30].

Based on the indicated impaired respiratory function in patients with acute and chronic lung diseases, in particular, COPD, the identified effects of
BSRS on the functional state of the human respiratory system when used in athletes, in particular, a significant increase in the vital capacity of the lungs, an increase in the excursion of the chest (due to the exhalation phase), an increase in peak power, and a decrease in maximum oxygen debt when performing aerobic and anaerobic physical exertion, as well as when used in a complex of methods of medical rehabilitation of patients who underwent COVID-associated pneumonia, in particular, an easing of breathing and deepening of inhalation and exhalation, an improvement in general wellbeing, a significant increase in $\mathrm{SaO}_{2}$ and external respiration rate, improvements in cardiac activity, psychological status, and physical and emotional states, a significant decrease in the severity of PTSD, it seems possible to recommend this method as a method of treatment and medical (pulmonological and pulmonary) rehabilitation of patients with acute and chronic lung diseases, in particular, diagnosed with "Other chronic obstructive lung disease."

The data obtained in this clinical study along with the results of other studies on this problem can serve as the basis for the development of valid clinical recommendations on the use of BSRS in the complex of medical and rehabilitation measures for acute and chronic lung diseases.

\section{Conclusion}

Based on the results of the study, it seems possible to conclude that the use of BSRS in the complex of rehabilitation measures significantly increases the effectiveness of medical rehabilitation of patients after COVID-associated pneumonia at a health resort. As a result of using the BSRS course (five sessions with five sessions every other day) in the complex of rehabilitation measures in patients who had COVIDassociated pneumonia, breathing became easier and deepened, general well-being improved, $\mathrm{SaO}_{2}$ increased significantly, indexes of external respiration increased, cardiac activity, psychological status, and physical and emotional condition improved, the severity of PTSD significantly decreased, and cognitive abilities increased.

Thus, the developed new physiotherapeutic technology of BSRS with high-intensity low-frequency sounds can be recommended as an effective physical method for inclusion in complex medical rehabilitation at the health resort stage of patients with COVIDassociated pneumonia and, based on the similarity of respiratory function disorders, in the therapy and medical (pulmonological and pulmonary) rehabilitation of patients with other respiratory diseases, in particular with COPD. 


\section{References}

1. Ministry of Health of the Russian Federation. Vremennye Metodicheskie Rekomendatsii "Meditsinskaya Reabilitatsiya Pri Novoi Koronavirusnoi Infektsii (COVID-19)" [Temporary guidelines "Medical Rehabilitation for the Novel Coronavirus Infection (COVID-19)"]. Version 2 (31.07.2020). Moscow, Russia: Minzdrav Rossii; 2020. p. 150. Available from: https:// www.edu.rosminzdrav.ru/fileadmin/user_upload/specialists/ covid-19/dop-materials/vmr_medreabilitacija_covid_versija2. pdf. [Last accessed on 2021 Aug 01].

2. Aleksandrova NP. Patogenez dykhatelnoi nedostatochnosti pri koronavirusnoi bolezni (COVID-19) [The pathogenesis of respiratory failure in Coronavirus disease (COVID-19)]. Integr Physiol. 2020;1(4):285-93.

3. Fesyun AD, Lobanov AA, Rachin AP, Yakovlev MY, Andronov SV, Konchugova TV, et al. Vyzovy i podkhody $\mathrm{k}$ meditsinskoi reabilitatsii patsientov, perenesshikh oslozhneniya COVID19 [Challenges and approaches to medical rehabilitation of patients with complications from COVID19]. Bull Rehabil Med. 2020;3:313. https://doi.org/10.38025/2078-1962-2020-97-3-3-13

4. Malyavin AG, Adasheva TV, Babak SL, Gubernatorova EE, Uvarova OV. Meditsinskaya reabilitatsiya bolnykh, perenesshikh COVID19 infektsiyu: Metodicheskie rekomendatsii [Medical rehabilitation of patients who have had the COVID19 infection: Guidelines]. Terapiya. 2020;6(39):148. https://doi.org/10.18565/ therapy.2020.5suppl.1-48

5. Meshcheryakova NN, Belevskii AS, Kuleshov AV. Provedenie Legochnoi Reabilitatsii u Patsientov s Novoi Koronavirusnoi Infektsiei (COVID-19) Vnebolnichnoi Dvustoronnei Pnevmonii: Metodicheskie Rekomendatsii [Pulmonary Rehabilitation in Patients with the novel Coronavirus Infection (COVID-19) with Community-Acquired Bilateral Pneumonia: Guidelines]. Moscow, Russia: FGOAU VO RNIMU Im. N.I. Pirogova Mindrava Rossii; 2020. p. 22.

6. Razumov AN, Ponomarenko GN, Badtieva VA. Meditsinskaya reabilitatsiya patsientov $s$ pnevmoniyami, assotsiirovannymi $s$ novoi koronavirusnoi infektsiei COVID-19[Medical rehabilitation of patients with pneumonia associated with the novel coronavirus infection COVID-19]. Probl Balneol Physiother Exerc Ther. 2020;97(3):5-13. https://doi.org/10.17116/kurort2020970315

7. Efimenko NV, Kaisinova AS, Ter-Akopov GN, Semukhin AN, Velikanov DI, Khodasevich LS, et al. Meditsinskaya reabilitatsiya na kurorte bolnykh, perenesshikh novuyu koronavirusnuyu infektsiyu (2019-nCoV) [Medical resort rehabilitation of patients who have had a novel Coronavirus infection (2019-nCoV)]. Resort Med. 2020;2:4-13.

8. Ter-Akopov GN, Efimenko NV, Kaisinova AS. Opyt FMBA Rossii po realizatsii tekhnologii meditsinskoi reabilitatsii $v$ sanatornokurortnykh usloviyakh bolnykh, perenesshikh koronavirusnuyu infektsiyu COVID-19 [The experience of the federal medical and biological agency of russia in the implementation of medical rehabilitation technologies in the health resort conditions for patients who have had COVID-19 Coronavirus infection]. Probl Balneol Physiother Exerc Ther. 2021;98(3):189-90.

9. Efimenko NV, Abramtsova AV, Simonova TM, Semukhin AN. Otsenka funktsionalnogo sostoyaniya kardiorespiratornoi sistemy u patsientov posle perenesennoi COVID-19 pnevmonii pri provedenii meditsinskoi reabilitatsii na kurorte [Assessment of the functional state of the cardiorespiratory system in patients recovering from COVID-19 associated pneumonia during medical rehabilitation at the resort]. Mod Issues Biomed. 2021;5(1):2-22. https://doi.org/10.51871/2588-0500_2021_05_01_2

10. Chuchalin AG. Tyazhelyi Ostryi Respiratornyi Sindrom (TORS) [Severe Acute Respiratory Syndrome (SARS)]; 2003. Available from: http://www.rmj.ru/articles/obshchie-stati/ tyaghelyy_ostryy_respiratornyy_sindrom_tors [Last accessed on 2021 Apr 22].

11. MalyavinAG,BabakSL,GorbunovaMV.Respiratornayareabilitatsiya post-COVID-19 patsientov [Respiratory rehabilitation of postCOVID-19 patients]. Russ Arch Intern Med . 2021;11(1):22-33. https://doi.org/10.20514/2226-6704-2021-11-1-22-33

12. Bogomolov AV, Dragan SP, Erofeev GG. Matematicheskaya model pogloshcheniyazvukalegkimi priakusticheskoistimulyatsii dykhatelnoi sistemy [Mathematical model of sound absorption by the lungs during acoustic stimulation of the respiratory system]. Doklady Akademii Nauk. 2019;487(1):97-101. https:// doi.org/10.31857/S0869-5652487197-101

13. Bubnova MG, Persiyanova-Dubrova AL, Lyamina NP, Aronov DM. Reabilitatsiya posle novoi koronavirusnoi infektsii (COVID-19): Printsipy i podkhody [Rehabilitation after a novel coronavirus infection (COVID-19): Principles and approaches]. CardioSomatika. 2020;11(4):6-14. https://doi.org/10.26442/222 17185.2020.4.200570

14. Khovanskaya GN, Yurchevskaya NV, Poluden VN, Siritsyna YC Primeneniya meditsinskoi reabilitatsii patsientov $s$ pnevmoniei, obuslovlennoi koronavirusom SARS-COV-2 [Applications of medical rehabilitation for patients with pneumonia associated with SARS-COV-2 coronavirus]. In: Aktualnye Problemy Meditsiny: Sbornik Materialov Itogovoi Nauchno-Prakticheskoi Konferentsii [Current Problems of Medicine: A Collection of Materials Presented at the Final Research and Practice Conference]. Grodno, Republic of Belarus: GrGMU; 2021. p. 894-8.

15. Shmonin AA, Maltseva MN, Melnikova EV, Mishina IE, Ivanova GE. Meditsinskaya reabilitatsiya pri koronavirusnoi infektsii: Novye zadachi dlya fizicheskoi i reabilitatsionnoi meditsiny $\mathrm{v}$ Rossii [Medical rehabilitation for coronavirus infection: New challenges for physical and rehabilitation medicine in Russia]. Bull Rehabil Med. 2020;3(97):14-21. https://doi.org/10.38025/2078-1962-2020-97-3-14-21

16. Pereborov AA, Razinkin SM, Kotenko NV. Sistema otsenk effektivnosti lecheniya [Treatment efficiency evaluation system]. In: Vosstanovitelnaya Meditsina i Reabilitatsiya 2009 [Restorative Medicine and Rehabilitation 2009]. Moscow, Russia: Russian Scientific Center for Medical Rehabilitation and Balneology; 2009. p. 166-7.

17. Samoilov AC, Razinkin SM, Fomkin PA, Petrova VV, Kish AA, Artamonova IA. Metodologicheskii podkhod $k$ otsenke funktsionalnykh rezervov sportsmenov tsiklicheskikh vidov sporta [Methodological approach to assessing the functional reserves of athletes in cyclic sports]. Sports Med. 2016;1:26-34.

18. Razinkin SM, Samoilov AC, Fomkin PA, Petrova VV, Artamonova IA, Kryntsilov Al, et al. Otsenka pokazatelei variabelnosti serdechnogo ritma u sportsmenov tsiklicheskikh vidov sporta [Assessment of heart rate variability indicaors in athletes of cyclic sports]. Sports Med. 2015;4:46-55.

19. Dragan SP, Bogomolov AV, Razinkin SM, Korchazhkina NB, Erofeev GG, Ivashin VA. Sposob Povysheniya Funktsionalnykh Rezervov Organizma [A Way of Increasing the Functional Reserves of the Body]. Invention Patent RU 2587970 C1 27.06.2016. Application No. 2015102474/14; 2015.

20. Dragan SP, Razinkin SM, Erofeev GG. Metod akusticheskoi stimulyatsii dykhatelnoi sistemy [Acoustic stimulation method for the respiratory system]. Biomed Eng. 2020;3:26-8.

21. Erofeev GG. Vliyanie bioakusticheskoi stimulyatsii dykhatelnoi sistemy sportsmenov na zhiznennuyu emkost legkikh [Influence of bioacoustic stimulation of the respiratory system of athletes on the vital capacity of the lungs]. Res Pract Med J. 2018;5(2):80-5. https://doi.org/10.17709/2409-2231-2018-5-2-9

22. Erofeev GG. Issledovanie individualnykh osobennostei dykhatelnoi sistemy sportsmenov-lyzhnikov $v$ zavisimosti ot fizicheskogo sostoyaniya [Study of the individual characteristics of the respiratory system of skiers depending on their physical condition]. Sports Med. 2020;10(1):30-6. 
23. Dragan SP, Bogomolov AV, Razinkin SM, Korchazhkina NB, Erofeev GG, Ivashin VA. Ustroistvo Dlya Zvukovoi Stimulyatsii Dykhatelnoi Sistemy [A Bioacoustic Respiratory System Stimulation Device]. Utility Model Patent RU 154260 U1, 20.08.2015. Application No. 2015102477/14; 2015.

24. Razinkin SM, Kish AA. Obektivnaya Psikhodiagnostika. Apparatno-Programmnyi Kompleks Diamed-MBS [Objective Psychodiagnostics. The Diamed-MBS Hardware and Software Complex]. Moscow, Russia: Nauchnaya Kniga; 2019. p. 228.

25. Soloveva NV, Makarova EV, Kichuk IV. Koronavirusnyi sindrom: Profilaktika psikhotravmy, vyzvannoi COVID-19 [The Coronavirus syndrome: Prevention of the psychological trauma caused by COVID-19]. Russkii Meditsinskii Zhurnal. 2020;9:18-22.

26. Tarabrina NV. Praktikum po Psikhologii Posttravmaticheskogo Stressa [A Practical Course on Post-Traumatic Stress Psychology]. St. Petersburg, Russia: Piter; 2001. p. 272.
27. Ponomarenko GN. Sensornoe Vospriyatie Nizkochastotnykh Akusticheskikh Kolebanii [Sensory Perception of LowFrequency Sound Vibrations]. PhD Thesis, Doctor of Medicine. Saint Petersburg; 1993. p. 38.

28. Bogomolov AV, Dragan SP. Matematicheskoe obosnovanie akusticheskogo metoda izmereniya impedansa dykhatelnogo trakta. Doklady akademii nauk [Mathematical justification of the acoustic method for measuring the impedance of the respiratory tract]. Dokl Biochem Biophys. 2015;464(5):623-5.

29. Dragan SP, Bogomolov AV. Metod akusticheskoi impedansometrii dykhatelnogo trakta. Meditsinskaya tekhnika [The method of acoustic impedancemetry of the respiratory tract]. Med Technol. 2015;5:19-21.

30. Olenskaya TL, Nikolaeva AG, Soboleva LV. Reabilitatsiya $\checkmark$ pulmonologii [Rehabilitation in the pulmonology]. Vitebsk: VGMU; 2016. p. 142. 